\title{
Assessment of the post partum Reproductive Performance of the Icelandic Dairy Cow During a 3 Year Period
}

\author{
By J. Eldon and Th. Ólafsson
}

\begin{abstract}
Eldon, J. and Th. Ólafsson: Assessment of the post partum reproductive performance of the Icelandic dairy cow during a 3 year period. Acta vet. scand. 1988, 29, 385-392. - The time of ovulation, artificial insemination (AI), conception and conception rate were studied in 412 Icelandic dairy cows from 2 different areas during a period of 3 years. To assess these parameters the progesterone level was measured in sequential samples of milk and the status of the genital organs evaluated by monthly rectal palpations. The time and number of AI was recorded and the conception rate calculated and compared with the other parameters. Furthermore, the length of the calving interval and gestation period were determined. The effects of year, season, area, age, herd and parity on these parameters were evaluated.

The overall mean for the time of first post partum ovulation was 42 days and varied from 29 to 49 days between herds. This is a considerably longer time than recorded for many other breeds of dairy cows. The effects of season, area and herd were significant for the time of first post partum ovulation.

The overall time of first post partum AI and conception were 74 days and 97 days, respectively. In spite of late onset of ovarian activity in Icelandic dairy cows, these two pararmeters are comparable to those of other breeds of cattle. The effects of season, parity and herd were significant for these two parameters.

The conception rate to first post partum AI was $59 \%$ and the number of AI per conception was 1.6. The time of conception correlated closely $(r=0.5)$ with the time of first post partum AI, but the conception rate to first AI increased and the number of AI per conception decreased with increasing time of first post partum AI.

The calving interval was 382 days and the gestation period was 287 days.

cattle; ovulation; AI; conception.
\end{abstract}

\section{Introduction}

The knowledge concerning the post partum reproductive performance of dairy cows has increased considerably during the last decade. Janson (1980) and Larsson et al. (1984) described the fertility traits of Swedish dairy cattle. Reimers et al. (1985) described the management factors affecting the reproductive performance of dairy cows in the Northeastern United States and Dobson \& $\mathrm{Ka}$ monpatana (1986) wrote a comrehensive review on the female cattle reproduction.
Earlier study of the Icelandic dairy cow suggested that the time from calving to first post partum ovulation was longer than in cows of other breeds (Eldon et al. 1985).

The objective of this study was to follow up this finding and to give more information about the post partum reproductive performance of the Icelandic dairy cow.

\section{Materials and methods}

The post partum reproductive status of 412 Icelandic dairy cows was studied over a 3 
year period, after the total of 739 calvings. The cows came from 9 herds in two areas. Area 1 (Eyjafjörour) in northern Iceland and area 2 (Skei $\delta$ ) in southern Iceland.

Three methods of approach were used. First, progesterone was assayed in systemically sampled milk to establish the status of the physiological activity of the post partum ovary. Second, the dates and number of AI were documented. Third, the physical status of the reproductive organs and pregnancy were followed by rectal palpation. This approach gave the approximate time of the first post partum ovulation, which is the fundamental physiological factor in the post partum reproductive status of the dairy cow. The time of conception and the conception rate were established. The results were categorized into years, seasons, areas, herds, age groups and individual animals and evaluated in context with these categories.

Milk samples for progesterone profiles were collected every 5 th day from day 10 post partum until first post partum AI. Milk samples were also taken at the time of AI. Progesterone was assayed in the fat free part by a radioimmunoassay technique using tritiated progesterone and charcoal as described by Oltner \& Edqvist $(1980,1981)$.

The time and number of AI was recorded. The genital organs were palpated once a month to evaluate the status of post partum recovery of the uterus and ovaries and to confirm pregnancy.

The animals, environment, management, sampling and progesterone assay method were described in detail by Eldon \& Olafsson (1986).

Statistical analysis of data was carried out using the one-way analysis of variance and correlation tests of the SPSS-X software on a Vax 750 computer.

\section{Results}

The overall means, standard deviations, minimum and maximum values for the time of first post partum ovulation, first artificial insemination and conception are shown in Table 1. The total conception rate to first post partum artificial insemination was $59 \%$ and the number of inseminations per conception was 1.6.

Table 1. Overall means (x), standard deviations (SD), minimum (min) and maximum (max) values for the number of days from calving to first post partum ovulation (Ov), artificial insemination (AI) and conception (Co).

\begin{tabular}{lrrr}
\hline & Ov & AI & Co \\
\hline $\mathrm{n}$ & 739 & 716 & 699 \\
$\mathrm{x}$ & 42 & 74 & 97 \\
$\mathrm{SD}$ & 26 & 24 & 42 \\
$\min$ & 10 & 25 & 34 \\
$\max$ & 247 & 247 & 265 \\
\hline
\end{tabular}

The mean number of days between calvings was 382 (SD = 48 days) and the mean number of days from conception to calving was 287 days $(\mathrm{SD}=8$ days).

There was a statistically significant positive correlation between the time of first post partum ovulation, first post partum AI and conception (Table 2).

Table 2. Correlation coefficients (r) and levels of significance (ls) for the correlations between the number of days from calving to first post partum ovulation (Ov), first post partum artificial insemination (AI) and conception (Co).

\begin{tabular}{ccccc}
\hline & $\mathrm{Ov}$ & \multicolumn{4}{c}{$\mathrm{AI}$} \\
\cline { 2 - 5 } & $\mathrm{r}$ & ls & $\mathrm{r}$ & ls \\
\hline $\mathrm{AI}$ & 0.4 & $* * *$ & - & \\
Co & 0.2 & $* * *$ & 0.5 & $* * *$ \\
\hline
\end{tabular}

Levels of significance: ${ }^{* * *}=(\mathrm{p}<0.001)$. 


\section{Year}

The time of first post partum ovulation and conception did not vary between the years of observation whereas a significant difference was noted for the time of first post partum AI (Table 3). The time (mean) of first post partum ovulation varied from 40 to 43 days with year (Table 4). The time of first post partum AI was 72 days for the 1st and 2nd year but increased to 77 days in the 3rd year (Table 4). The time of conception was 98 days for the first 2 years but decreased to 94 days during the 3 rd year (Table 4 ).

Table 3. Levels of significance from the one-way analysis of variance tests. $\mathrm{Ov}=$ ovulation, $\mathrm{AI}=\mathrm{ar}-$. tificial insemination, $\mathrm{Co}=$ conception.

\begin{tabular}{lrrr} 
& \multicolumn{3}{c}{ Category } \\
\cline { 2 - 4 } Source of & & & \\
variation & Ov & AI & Co \\
\hline Year & ns & $*$ & ns \\
Season & $* * *$ & $* * *$ & $* * *$ \\
Area & $* * *$ & ns & ns \\
Parity & ns & $* *$ & $* *$ \\
Herd & $* * *$ & $* * *$ & $* *$ \\
Herd 1 & ns & $*$ & ns \\
Herd 2 & ns & $* * *$ & $* *$ \\
Herd 3 & ns & $* * *$ & $* *$ \\
Herd 4 & ns & $* *$ & ns \\
Herd 5 & $*$ & ns & $* *$ \\
Herd 6 & $* * *$ & $*$ & $* *$ \\
Herd 7 & $* * *$ & ns & ns \\
Herd 8 & ns & $*$ & ns \\
Herd 9 & ns & ns & ns \\
Ketosis & $*$ & $*$ & ns \\
\hline
\end{tabular}

Levels of significance: $\mathrm{ns}=$ not significant $(\mathrm{p}>0.05), *=(\mathrm{p}<0.05),{ }^{* *}=(\mathrm{p}<0.01),{ }^{* * *}=$ $(\mathrm{p}<0.001)$.

* The levels of significance between all herds and for each herd compared to the values of the rest of the herds, within each area, combined.
Table 4. The mean values (x) and standard deviations (SD) for the number of days from calving to first post partum ovulation $(\mathrm{Ov})$, first post partum artificial insemination (AI) and to conception (Co). The values are divided by year, season, area, herd, parity and ketosis.

\begin{tabular}{|c|c|c|c|}
\hline & \multicolumn{3}{|c|}{$\begin{array}{l}\text { Time of } \\
\text { First post partum }\end{array}$} \\
\hline & Ov & & $\mathrm{Co}$ \\
\hline & $\overline{x(S D)}$ & $\overline{x(S D)}$ & $\overline{\mathrm{x}(\mathrm{SD})}$ \\
\hline & \multicolumn{3}{|c|}{ (Number of days) } \\
\hline \multicolumn{4}{|l|}{ Year } \\
\hline Year $1(n=245)$ & $40(22)$ & $72(22)$ & $98(42)$ \\
\hline Year $2(n=248)$ & $43(29)$ & $72(24)$ & $98(44)$ \\
\hline Year $3(n=246)$ & $42(27)$ & $77(25)$ & 94 (39) \\
\hline \multicolumn{4}{|l|}{ Season } \\
\hline \multicolumn{4}{|l|}{ Autumn } \\
\hline \multicolumn{4}{|l|}{ Sept.-nov. } \\
\hline \multicolumn{4}{|l|}{ Winter } \\
\hline \multicolumn{4}{|l|}{ Des.-Feb. } \\
\hline \multicolumn{4}{|l|}{ Spring } \\
\hline \multicolumn{4}{|l|}{ Mar.-May } \\
\hline \multicolumn{4}{|l|}{ Summer } \\
\hline \multicolumn{4}{|l|}{ Jun.-Aug. } \\
\hline \multicolumn{4}{|l|}{ Area } \\
\hline Area $1(n=404)$ & $45(27)$ & $73(24)$ & $96(44)$ \\
\hline Area $2(n=335)$ & $38(24)$ & $74(24)$ & 97 (39) \\
\hline \multicolumn{4}{|l|}{ Herd } \\
\hline Herd $1(n=86)$ & $47(24)$ & $79(24)$ & 99 (43) \\
\hline Herd $2(n=89)$ & $43(24)$ & $63(17)$ & $86(41)$ \\
\hline Herd $3(n=121)$ & $42(36)$ & $81(27)$ & $105(46)$ \\
\hline Herd $4(n=108)$ & $47(21)$ & $67(21)$ & $92(41)$ \\
\hline Herd $5(n=41)$ & $45(25)$ & $81(24)$ & $115(48)$ \\
\hline Herd $6(n=89)$ & $29(18)$ & 78 (19) & $87(28)$ \\
\hline Herd $7(n=57)$ & $49(31)$ & $71(28)$ & 94 (38) \\
\hline Herd $8(n=66)$ & $36(22)$ & $68(26)$ & 99 (44) \\
\hline Herd $9(n=82)$ & $38(20)$ & $74(23)$ & $101(40)$ \\
\hline \multicolumn{4}{|l|}{ Parity } \\
\hline \multicolumn{4}{|l|}{ Primiparous } \\
\hline$(n=198)$ & $40(31)$ & $78(25)$ & 104 (41) \\
\hline \multicolumn{4}{|l|}{ Multiparous } \\
\hline $\begin{array}{l}(\mathrm{n}=541) \\
\text { Ketosis }\end{array}$ & $42(24)$ & $72(23)$ & $94(41)$ \\
\hline \multicolumn{4}{|l|}{ Cows with } \\
\hline ketosis $(n=41)$ & $41(25)$ & $78(23)$ & $97(45)$ \\
\hline Cows without & & & \\
\hline ketosis $(n=698)$ & $38(30)$ & $73(24)$ & $94(44)$ \\
\hline
\end{tabular}


The conception rate to first post partum AI increased from $54 \%$ in the 1st year to $65 \%$ in the $3 \mathrm{rd}$ and the number of AI per conception decreased from 1.7 to 1.5 during the same period (Table 5).

Table 5. The conception rate (\%) to first post partum AI (a) and the number of AI per conception (b).

\begin{tabular}{lcccc}
\hline & \multicolumn{3}{c}{ Year } & \\
\cline { 2 - 4 } & 1 & 2 & 3 & Total \\
\hline Areal 1 & 55 & 51 & 64 & 57 \\
a & 1.6 & 1.7 & 1.5 & 1.6 \\
b & & & & \\
Area 2 & 52 & 66 & 65 & 61 \\
a & 1.9 & 1.5 & 1.6 & 1.7 \\
b & & & & \\
Both areas & & & & \\
combined & 54 & 57 & 65 & 59 \\
a & 1.7 & 1.6 & 1.5 & 1.6 \\
b & - & - & - & 59 \\
Primiparous cows & & & 1.6 \\
a & - & - & - & \\
b & & & & 60 \\
Multiparous cows & - & - & - & 1.6 \\
a & - & - & - & \\
b & & & &
\end{tabular}

\section{Season}

A significant seasonal difference was observed for the time of first post partum ovulation, AI and conception (Table 3). The time of first post partum ovulation increased from 33 days in the autumn to 50 days in the winter and spring and decreased again in summer to 31 days (Table 4).

The time of first post partum AI decreased from 78 days in the autumn to 67 days in the summer and the time of conception decreased from 105 days in the autumn to 87 days in the summer (Table 4).

The correlation coefficient (r) for the correlation between the time of first post partum $\mathrm{AI}$ and conception categorized by season was 0.95 ( $\mathrm{p}<0.001)$.

\section{Area}

There was a significant geographical difference in the time of first post partum ovulation but not in the time of first post partum AI or conception (Table 3). The time of first post partum ovulation for area 1 and 2 was 45 and 38 days, respectively. The time of first post partum AI was 73 and 74 days and the time of conception was 96 and 97 days for area 1 and 2, respectively (Table 4).

The conception rate to first post partum AI was $57 \%$ and $61 \%$ and the numbers of inseminations per conception were 1.7 and 1.6 for the two areas (Table 5).

In area $1,22 \%$ of the cows were inseminated at the time of first post partum ovulation ( $x$ $=64, \mathrm{SD}=17$ days post partum) and $64 \%$ conceived. In area $2,12 \%$ of the cows were inseminated at the time of first post partum ovulation $(x=65$, SD $=26$ days post partum) and $53 \%$ conceived.

In area $1,8 \%$ of the cows had high progesterone levels in the milk at the time of $\mathrm{AI}$ as compared with $4 \%$ in area 2 .

\section{Herd}

The total effect of herd was significant for the time of first post partum ovulation, first post partum AI and conception (Table 3). The range of mean values for the time of first post partum ovulation varied from 29 to 49 days between herds (Table 4 ), and each of 3 herds were significantly different from the other herds combined (Table 3).

The range of mean values for the time of first post partum AI varied from 63 to 81 days between herds (Table 4), and each of six herds were significantly different from the other herds combined (Table 3 ).

The range of mean values for the time of conception varied from 86 to 115 days between herds (Table 4), and each of 4 herds differed significantly from the other herds combined (Table 3). 
The conception rate to first post partum AI varied from 51 to $65 \%$ and 48 to $83 \%$ between herds in area 1 and 2 respectively. The number of AI per conception varied from 1.5 to 1.7 and 1.2 to 1.9 between herds in area 1 and 2, respectively.

The correlation coefficients ( $r$ ) between conception rate and number of AI per conception and between the conception rate to first post partum AI and time of conception were 0.90 and 0.42 , respectively ( $p<0.001$ ). There was a positive correlation between the time of first post partum AI and the conception rate to that insemination $(r=0.2$ ( $p$ $<0.01)$ ).

\section{Animal}

The time of first post partum ovulation was significantly correlated within animal $(r=$ $0.5, \mathrm{p}<0.001$ ), whereas the time of first post partum AI, conception and the number of AI showed no significant correlation. The mean variation for the time of gestation for each cow was 7 days (SD $=8$ days).

\section{Age and parity}

The mean age of the cows decreased and the percentage of primiparous cows increased between years (Table 6). Age did not correlate significantly with the time of first post partum ovulation or conception, $r=0.06$, -

Table 6. Number (n) and age ( $x$, mean number of years; SD, standard deviation) of cows in years and number of primiparous cows (\%), divided by years and areas.

\begin{tabular}{lccccc}
\hline & \multicolumn{3}{c}{ Year } & \multicolumn{3}{c}{ Area } \\
\cline { 2 - 6 } & 1 & 2 & 3 & 1 & 2 \\
\hline $\mathrm{n}$ & 256 & 268 & 256 & 426 & 354 \\
$\mathrm{x}$ & 5.0 & 5.1 & 4.7 & 5.3 & 4.3 \\
$\mathrm{SD}$ & 2.5 & 2.7 & 2.3 & 2.8 & 2.0 \\
Number of & & & & & \\
primiparous & & & & & \\
cows (\%) & 22 & 24 & 25 & 20 & 27 \\
\hline
\end{tabular}

0.04 , respectively. Age correlated significantly with the time of first post partum AI, $r=-0.11(p<0.01)$.

Parity did not have a significant effect on the time of first post partum ovulation though primiparous cows ovulated slightly sooner after calving than did multiparous cows (Tables 3 and 4). The effect of parity was significant for the time of first post partum AI and conception (Tables 3 and 4). The time of first post partum AI and the time of conception were significantly longer in primiparous than multiparous cows (Tables 3 and 4). The conception rate to first post partum AI was $59 \%$ and $60 \%$ for primiparous and multiparous cows, respectively and the number of AI per conception was 1.6 for both groups (Table 5).

\section{Ketosis}

Cows with clinical ketosis (ketone bodies in blood $>10 \mathrm{mmol} / \mathrm{l}$ ) ovulated significantly later than cows with low levels of ketone bodies in their blood (Tables 3 and 4). These cows were also inseminated (first post partum AI) significantly later, however, day of conception was not changed (Tables 3 and 4).

\section{Discussion}

Our results show that the first post partum ovulation occurs considerably later in the Icelandic dairy cow, than described for various other breeds of dairy cows (King et al. 1976, Bulman \& Lamming 1978, Mather et al. 1978, Larsson et al. 1984, Haraszti et al. 1985). In spite of this relatively late onset of ovarian activity, the rate and time of conception is comparable to that observed in other breeds (Janson 1980, Larsson et al. 1984).

As the effect of year on the time of first post partum ovulation was not significant, it appears that a physiological function like the onset of ovarian activity after calving is, on 
the whole, stable for a large group of animals over a long time period. The effect of year on the time of conception was not significant although the conception rate to first post partum $\mathrm{AI}$ increased from $54 \%$ to $65 \%$ from the 1st to the 3rd year and the number of AI per conception decreased accordingly. A possible explanation for this is an increase in the time of first post partum AI from the 1 st to the 3rd year.

Seasons obviously play a part in the time of onset of ovarian activity after calving. The time of first post partum ovulation increased from autumn to winter and decreased from spring to summer. A plausible explanation for these changes are: i) variable nutritional (energy) levels in different seasons; ii) seasonal changes in the length of sunlight and of gonadotropin secretion; iii) seasonal differences in physical exercises and social behavior (Bulman \& Lamming 1978, Butler et al. 1981, McNatty et al. 1984, Montgomery et al. 1985). The seasonal changes in the time of conception correlated closely with the changes in the time of first post partum AI. The time of conception increased with increasing time of first post partum AI. This is emphasized in the close total correlation of the time of first post partum ovulation with the time of conception. These correlations clearly indicate the importance of the time of the first post partum ovulation as the fundamental physiological factor governing the post partum reproductive performance of the dairy cow. The seasonal changes in the time of first post partum AI reflect the attempt of the farmer to control the time (month) of calving.

There was a significant geographical difference in the time of first post partum ovulation but not for the time of AI or conception. Cows in area 2 had a shorter time to first post partum ovulation, higher conception rate to first post partum $\mathrm{AI}$ and lower percentage of luteal phase inseminations than area 1.

The cows that were inseminated at the time of first oestrus, had a higher conception rate than the average rate found for cows in area 1. Conception to AI prior to any size in progesterone is in contradiction with the conclusions of Butler et al. (1981) who stated that the first post partum increase in plasma progesterone was due to follicular luteinization rather than to ovulation. This finding is also in contradiction with Duby et al. (1985) who found that $\mathrm{CL}$ removed after first ovulation ( $<25$ days post partum) were smaller and contained fewer live cells than those obtained after subsequent ovulations and the development and maintenance of that $\mathrm{CL}$ was therefore impeded. The apparent contradictions of our results with these findings are probably because our cows that were inseminated during first post partum ovulation were inseminated 65 days post partum, on the average, and conception rate increased with increasing time from calving to first AI probably because the incidence of "short cycle" decreases with increasing time from calving to first ovulation (Britt 1975, Kindahl et al. 1982, Larsson et al. 1984).

The significant variation found between herds in the time of first post partum ovulation, $\mathrm{AI}$ and conception are most plausibly explained by differences in the management of the herds although environmental and even genetic factors cannot be ruled out (King et al. 1976, Janson 1980, Coleman et al. 1985, Reimers et al. 1985). The number of herds that were each significantly different from other herds combined varied between parameters. One herd (herd 6) was significantly different from the rest of the herds in the time of first post partum ovulation, AI and conception. This herd had the shortest time to first post partum ovulation, had the highest conception rate and the fewest number 
of AI per conception. The herd that had the shortest time to first post partum AI (herd 2) also had the shortest time to conception. This herd had low conception rate to first post partum AI (51\%) and a high number of inseminations per conception (1.7). Coleman et al. (1985) reported that the interval from calving to first service was a major determinant of calving interval. In spite of lower conception rate, early AI is clearly advantageous. The significant correlation found within animal in the time of first post partum ovulation indicates a genetic effect on the ovarian activity. This genetic effect makes it feasible to breed for early post partum ovarian activity.

Age did not seem to have much effect on the reproductive parameters studied, as a significant negative correlation with age was only found for the time of first post partum AI. This significance is reflected in the correlation of parity with the time of first post partum AI and conception. Our findings agree with those of Bulman \& Lamming (1978) and Larsson et al. (1984) who reported that onset of post partum ovarian cyclicity varied insignificantly with age and parity. Rosenberg et al. (1977), on the other hand, found that primiparous cows ovulated significantly later after calving than did multiparous cows, and Coleman et al. (1985) reported that poor reproductive performance increased with age. The mean number of days between calvings was 382 days. This value is close to the findings of Svavarsson \& Jónmundsson (1985) who reported an average value of 385.4 days for 112.000 Icelandic dairy cows. The mean length of gestation was 287 days which is the same as reported for Charollais and South Devon cattle (Noakes 1986).

Ketosis had a significant delaying effect on the time of first post partum ovulation and therefore had a delaying effect on the time of first post partum AI. This effect was not reflected in delayed time of conception.

The effects of season and herd had the greatest influence on the time of first post partum ovulation, AI and conception. The time of first post partum AI affected the time of conception more than did the conception rate to first AI. This effect is reflected throughout the results.

\section{Acknowledgement}

We thank Prof. H. Kindahl at the Department of Obstetrics and Gynaecology, Swedish University of Agricultural Sciences and Dr. G. Georgsson at the Institute for Experimental Pathology, University of Iceland, for reviewing the manuscript. Dr. H. Thorsson at the Computing Services, University of Iceland, for his assistance with the statistical analysis and Mr. G. Steindórsson, The Agricultural Society of Eyjafjörour, for his assistance on the farms. This study was supported by the Icelandic Science Fund and the International Atomic Energy Agency.

\section{References}

Britt JH: Early postpartum breeding in dairy cows: A review. J. Dairy Sci. 1975, 58, 266-271.

Bulman CD, Lamming GE: Milk progesterone levels in relation to conception, repeat breeding and factors influencing acyclicity in dairy cows. J. Reprod. Fert. 1978, 54, 447-458.

Butler WR, Everett $R W$, Coppock CE: The relationships between energy balance, milk production and ovulation in postpartum Holstein cows. J. Anim. Sci. 1981, 53, 742-748.

Coleman DA, Thayne WV, Dailey RA: Factors affecting reproductive performance of dairy cows. J. Dairy Sci. 1985, 68, 1793-1803.

Dobson H, Kamonpatana M: A review of female cattle reproduction with special reference to a comparison between buffaloes, cows and zebu. J. Reprod. Fert. 1986, 77, 1-36.

Duby RT, Browning T, Carey D, Black DL: Progesterone synthesis and histology of post partum bovine corpora lutea. Theriogenology 1985, 23, 619-630.

Eldon J, Ólafsson TH, Thorsteinsson TH: A survey of the postpartum reproductive performance of 
dairy cows with fertility problems in southern Iceland. Acta vet. scand. 1985, 26, 431-441.

Eldon J, Olafsson TH: The postpartum reproductive status of dairy cows in two areas in Iceland. Acta vet. scand. 1986, 27, 421-439.

Haraszti J, Huszenicza G, Molnár L, Solti L, Csernus $V$ : Postpartal ovarian activity of healthy cows and affected by subclinical metabolic disorders. Anim. Reprod. Sci. 1985, 9, 125-136.

Janson L: Studies on fertility traits in Swedish dairy cattle. Acta Agric. Scand. 1980, 30, 109-124.

Kindahl $H$, Edqvist L-E, Larsson $K$, Malmqvist Aं: Influence of prostaglandins on ovarian function post partum. In: "Factors influencing fertility in the postpartum cow.« (eds. H. Karg \& E. Schallenberger), Martinus Nijhoff Publishers, The Hague, Current Topics in Veterinary Medicine and Animal Science, vol. 20, 1982, 173-196.

King GJ, Hurnik JF, Robertson HA: Ovarian function and estrus in dairy cows during early lactation. J. Anim. Sci. 1976, 42, 688-692.

Larsson $K$, Janson L, Berglund B, Edqvist L-E, Kindahl $H$ : Postpartum reproductive performance in dairy cows. I. Influence of animal breed and parity. Acta vet. scand. 1984, 25, 445-461.

Mather EC, Camper PM, Vahdat F, Whitmore HL, Gustafsson BG: Assessment of ovarian activity in the postpartum dairy cow by use of a milk progesterone assay. Theriogenology 1978, 10, 119129.

McNatty KP, Hudson N, Gibb M, Henderson KM, Lun S, Hearth D, Montgomery GW: Seasonal differences in ovarian activity in cows. J. Endocr. 1984, 102, 189-198.

Noakes DE: Fertility and obstetrics in Cattle. Blackwell Scientific Publications, London 1986 p. 30.

Montgomery GW, Scott IC, Hudson N: An interaction between season of calving and nutrition on the resumption of ovarian cycles in postpartum beef cattle. J. Reprod. Fert. 1985, 73, 45-50.

Oltner R, Edqvist L-E: Progesteron i mjölk (Progesterone in milk). In: "Progesteron i mjölk «. SHS Communication no. 101, 1980, 4-28.

Oltner R, Edqvist L-E: Progesterone in defatted milk: Its relation to insemination and pregnancy in normal cows as compared with cows on problem farms and in individual problem animals. Brit. vet. J. 1981, 137, 78-87.
Reimers TJ, Smith RD, Newman SK: Management factors affecting reproductive performance of dairy cows in the Northeastern United States. J. Dairy Sci. 1985, 68, 963-972.

Rosenberg M, Herz Z, Davidson M, Folman Y: Seasonal variations in post partum plasma progesterone levels and conception in primiparous and multiparous dairy cows. J. Reprod. Fert. 1977, 51, 363-367.

Svavarsson E, Jónmundsson JV: Bil milli burסa hjá islenskum kúm (The calving interval of Icelandic dairy cows). J. Agr. Red. Icel. 1985, 7, 73-87.

\section{Sammanfattning}

Bestämning av postpartumperiodens reproduktionsstatus hos isländska mjölkkor under 3 àrs period.

Tiden för ovulation, konstgjord inseminering (ai), konception och konceptionsfrekvens undersöktes hos 412 isländska mjölkkor från två olika områden under 3 års tid. För att få fram dessa parametrar bestämdes progesteronnivån $\mathrm{i}$ mjölkprover och genitalorganens kondition månadsvis med rektalpalpation. Tidpunkten för och antal ai registrerades och konceptions- frekvensen jämfördes med andra parametrar. Dessutom bestämdes längden av kalvningsintervallet och dräktighetstiden. Effekten av år, årstid, område, ålder, besättning och paritet blev utvärderat.

Medeltalet för tiden för den första ovulationen efter partus var 42 dagar och varierade från 29 till 49 dagar mellan besättningar. Detta är betydligt längre tid en vad som rapporterats för många andra raser av mjölkkor. Effekterna av årstid, område och besättning var signifikant för tidpunkten för den första ovulationen efter partus.

Medeltiden för första ai och konception efter partus var 74 respektive 97 dagar. Även om äggstocksaktiviteten börjar sent hos isländska mjölkkor är dessa två parametrar jämnförbara med de från andra raser av mjölkkor. Effekterna av årstid, paritet och besättning var signifikanta för dessa två parametrar. Konceptionsfrekvensen och första ai efter partus var $59 \%$ och antal ai per konception var 1.6.

Konceptionstid korrelerade med första ai efter partus $(r=0.5)$, men konceptionsfrekvensen med första ai ökade och antal ai per konception minskade med ökad tid till första ai efter partus. Kalvningsintervallet var 382 dagar och bördstiden var 287 dagar.

(Received February 16, 1988).

Reprints may be requested from: Jón Eldon, Institute for Experimental Pathology, P. O. Box 8540, Is-128 Reykjavik, Iceland. 